\title{
UNUSUAL PRESENTATION OF PULMONARY SARCOIDOSIS
}

\author{
Gordana Antonijevic ${ }^{1}$, Dragan Stanojevic ${ }^{2}$, Valentina Opancina ${ }^{3,4}$ \\ 'Hospital Special for Lung Diseases "Ozren", Sokobanja, Serbia \\ ${ }^{2}$ Special Hospital for Nonspecific Lung Diseases "Sokobanja", Sokobanja, Serbia \\ ${ }^{3}$ Department of Radiology, Faculty of Medical Sciences, University of Kragujevac, Kragujevac, Serbia \\ ${ }^{4}$ Clinical Center Kragujevac, Kragujevac, Serbia
}

\section{НЕОБИЧНА ПРЕЗЕНТАЦИЈА ПЛУЋНЕ САРКОИДОЗЕ}

\author{
Гордана Антонијевић', Драган Станојевић², Валентина Опанчина 3,4 \\ ${ }^{1}$ Специјална болница за плућне болести "Озрен", Сокобана \\ ${ }^{2}$ Специјална болница за неспециифичне плућне болести "Сокобања", Сокобања \\ ${ }^{3}$ Катедра за радиологију, Универзитет у Крагујевиу, Србија, Факултет медицинских наука, Катедра за радиологију \\ ${ }^{4}$ Клинички Центар Крагујеваи, Крагујеваи
}

\begin{abstract}
Sarcoidosis is a systemic granulomatous disease of unknown etiology, with ambiguous presentation. Pulmonary sarcoidosis is rare and its presentation is untypical. In this paper we present a case of pulmonary sarcoidosis with unspecific presentation. In 1995, a 36-year-old pilot was presented with no previous history of any notable illness and without any symptoms. Chest radiography showed a lesion and Ziehl-Neelsen staining showed the presence of acidresistant bacteria, after which antituberculotic therapy started. After multiple hospitalizations, in 2011, radiography showed changes in lungs that resemble sarcoidosis or tuberculous sequelae. In 2016, tuberculosis was excluded and revised pathohistological findings of granulomatous inflammation in 2003, clinical presentation and radiography findings suggested sarcoidosis with slow progression and fibrous indurative changes in upper lung lobes with the presence of low-grade lymphocyte alveolitis.
\end{abstract}

Key words: sarcoidosis; tuberculosis; lung diseases, interstitial.

\section{INTRODUCTION}

Sarcoidosis is a systemic granulomatous disease of unknown etiology, characterized by an enhanced immune response and formation of granulomas in any organ. It is reported that the prevalence of sarcoidosis in men is $16.5 / 100.000$ and 19/100,000 in women (1). Most often sarcoidosis is presented in patients younger than 40 years (2). Pulmonary changes are seen in $90 \%$ and changes can rarely be found in parotid and other salivary glands, eyes, joints, heart, liver, brain, nerves (3). Clinical presentation includes fatigue, weight loss, fever, nodosus erythema, peripheral lymphadenopathy, hepatomegaly, splenomegaly, polyarthralgia (2). The role of imaging in diagnosis is outstanding, especially chest X-ray and computed tomography (CT) (4). Based on a radiological picture of the lung, four radiological stages of sarcoidosis are distinguished: a. Bihilar lymphadenopathy; b. Bihilar lymphadenopathy with changes in pulmonary interstitial

\section{САЖЕТАК}

Саркоидоза је системска грануломатозна болест непознате етиологије, с двосмисленом презентацијом. Плућна саркоидоза је ретка и њена презентачија је нетипична. У овом раду представљамо случај плућне саркоидозе са неспецифичном презентаиијом. Године 1995. хоспитализован је тридесетшестогодишьи пилот, без претходне историје било какве значајне болести и без симптома. Радиографија грудног коча показала је лезију, а бојење Ziehl-Neelsen присуство ацидорезистентних бацила, након чега је примењена антитуберкулотска терапија. После вишеструких хоспитализачија, у 2011. години, радиографија је показала промене у плућима које подсећају на саркоидозу или туберкулозне секвеле. У 2016. години искључена је туберкулоза и ревидирани су патохистолошки налази грануломатозне инфламачије из 2003, а клиничка презентација и налази радиографије сугерисали су саркоидозу са спором прогресијом и фиброзним индуративним променама у горњим плућним лобусима уз присуство нискоградусног лимфоичтнног алвеолитиса.

Кључне речи: саркоидоза; туберкулоза; болести плућа, интерстицијалне.

space; c. Interstitial changes without hilum lymphadenopathy; d. Formation of fibrotic changes $(4,5)$. The most valuable for diagnosis is pathohistological evidence of epithelioid non-caseating granuloma after the performed biopsy (6). In this paper we present a case of pulmonary sarcoidosis with unspecific presentation.

\section{CASE REPORT}

In 1995, a 36-year-old pilot came to an annual checkup at the tertiary medical center, with no previous history of any notable illness and without any symptoms. He was an ex-smoker. Laboratory results, spirometry and gas analysis were in normal range. Chest radiography showed a lesion in the right upper pulmonary lobe. He was hospitalized in October 1995 at this institution with the duration of 23 days. During that time, lung tuberculosis 
was suspected, but sputum examinations with direct bacilloscopy did not show acidoresistent bacilli (ARB) and Lowenstein-Jensen (Low) cultures were negative. CT scan showed an infiltration surrounded with satellite lesions in the right lung apex. Transbronchial biopsy was done and pathohistological finding $(\mathrm{PH})$ was bronchitis and granulomatous peribronchitis. Ziehl-Neelsen staining showed the presence of acid-resistant bacteria, after which triple antituberculotic (ATL) therapy (isoniazid (H), rifampicin (R), pyrazinamide $(\mathrm{Z})$ ) was started at the Special Hospital for Pulmonary Diseases "Ozren" Sokobanja where he was referred. The treatment lasted for 2 months, during which Low cultures and direct microscopy remained negative. Two years later, he was hospitalized for the second time at the Special Hospital for Pulmonary Diseases "Ozren" Sokobanja, for 3 months, during which time new lesions were presented in left lung and right apex and showed poor radiological regression. An open lung biopsy was made and pathohistological findings were in favor of chronic granulomatous inflammation of tuberculous nature. The treatment was started with four ATL drugs (H, R, ethambutol (E) and streptomycin (S)), with an extension phase with three ATL drugs (H, R, E) in Ozren. In August 1997, Low culture was positive ( 7 colones) after which it remained negative. Resistance test showed sensitivity to all ATL. The patient was treated for a total of 9 months.

In 2002, the patient came with an elevated body temperatures up to $38^{\circ} \mathrm{C}$, cough, increased sweating and fatigue during exercise. He was hospitalized at the Special Hospital for Pulmonary Diseases "Ozren" Sokobanja for 3 months. Chest radiography showed progression of lung lesions (Figure 1). Two samples of sputum examined by direct microscopy were positive. Relapse treatment was started and conducted with 5 ATL drugs. Pathohistological

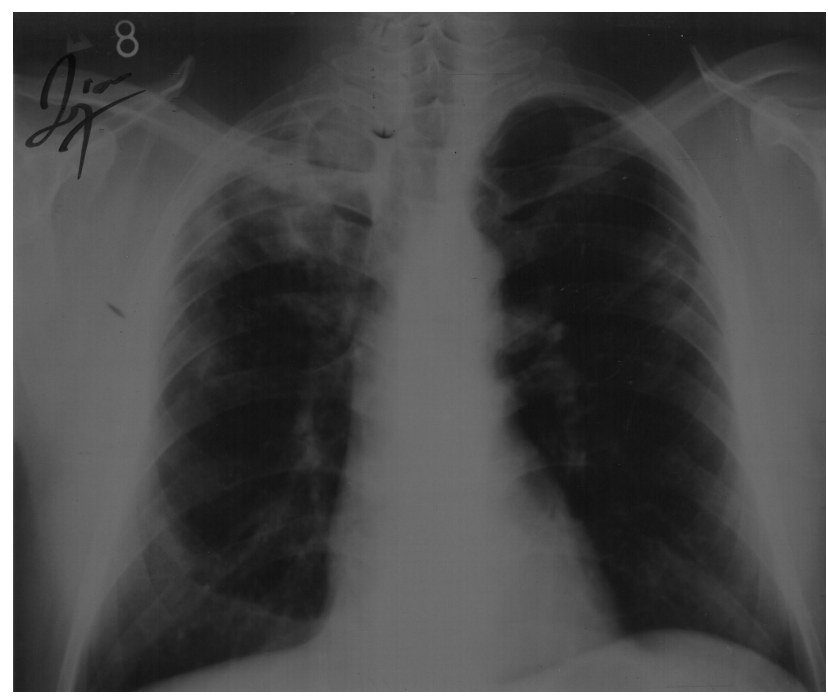

Figure 1. Chest radiography made in 2002 showed consolidations in right upper and mid lung lobe and left mid lobe. samples from 1995 and 1997 were revised after which granulomatous inflammation was seen and sarcoidosis was suspected.

In 2003, chest radiography showed progression and new lesions in the upper left lobe. Laboratory results were in the normal range, bronchoalveolar lavage showed lymphocytic alveolitis. Samples from 1995 and 1997 were revised and showed granulomatous inflammation, most likely within the framework of sarcoidosis. Immunosuppressive therapy (with chemioprofilaxys eutison - izoniazide + vitamin B6) was indicated and the treatment lasted for 6 months.

In 2008 and 2010 two CT scans of thorax were made. The first one showed fibrous indurative changes in both upper pulmonary lobes and the CT from 2010 (Figure 2) showed progression of lung lesions with mediastinal lymphadenopathy which suggested chronic sarcoidosis.

In 2011 the patient was admitted to the other institution. He was presented with cough, fatigue and edema of right ankle joint. Laboratory analysis were within the limits of reference values. Radiography of feet and hands showed initial degenerative changes.

Bronchial findings were normal: bronchoalveolar lavage (BAL), trancbronchial needle aspiration (TBNA) on trachea, transbronchial biopsy (TBB) as well as aspirate and cytology, ARB and Low. BAL showed in the sediment: erythrocytes, cylindrical cells, macrophages

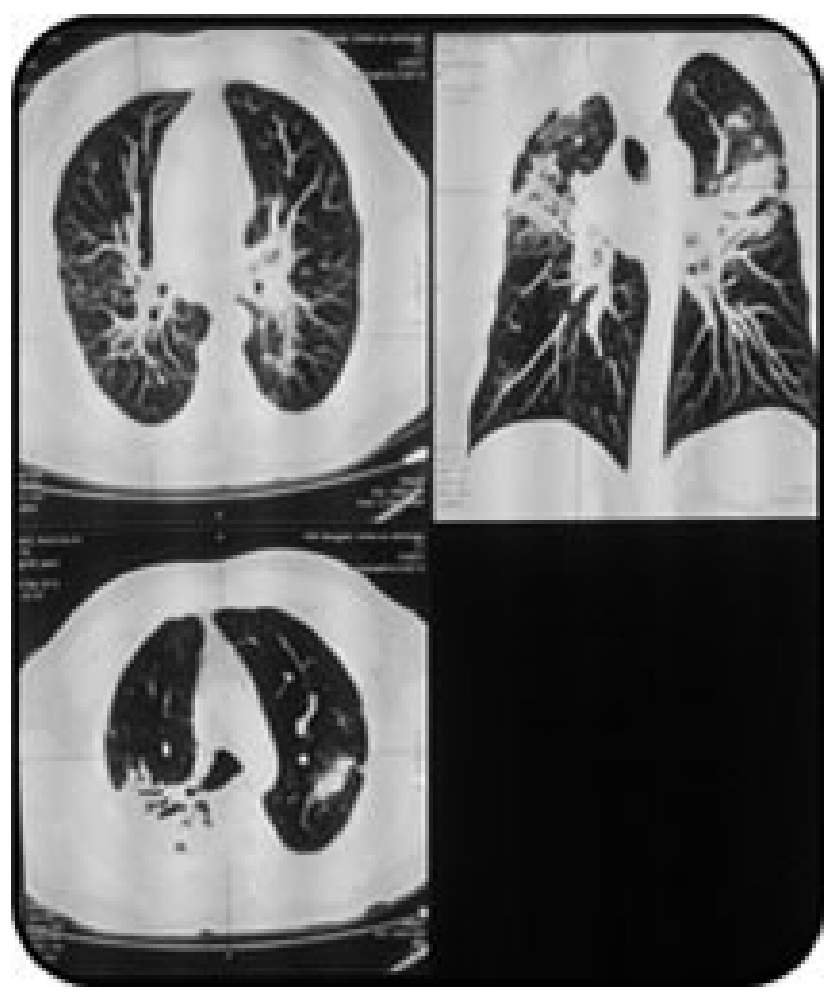

Figure 2. CT scan of thorax, made in 2010. It showed progression of lung lesions with mediastinal lymphadenopathy which suggested chronic sarcoidosis 
$48 \%$, seg. $35 \%$, eozynophilles $5 \%$ and Ly $12 \%$. ARBs were not seen from the bronchial aspirate in the direct preparation. PH finding from TBNA and TBB was nonspecific. Pulmonary function tests showed mixed ventilation disorder of a mild degree. Carbon monoxide (CO) diffusion was normal. Saturation was $98 \%$. CT scan of thorax was performed, and signs of specific inflammation, sarcoidosis or neoplasm were not found. Radiography showed changes in lungs that resemble sarcoidosis or tuberculous sequelae.

In 2016 a new set of examinations was performed due to the presence of symptoms within the last 6 months (fatigue, shoulder and pelvis pain, with limited mobility and right ankle edema). The patient denied respiratory symptoms. Bronchial examination was normal (BAL and aspirate). Spirometry showed mild obstructive disorder. $\mathrm{CO}$ diffusion was decreased $(75.5 \%)$ and saturation was 99\%. Thoracic CT scan was also performed (Figure 3). Immunosuppressive treatment continued.

In the absence of the expected radiological regression of lung lesions, in addition to adequately applied ATL therapies, tuberculosis was excluded. Revised $\mathrm{PH}$ finding of granulomatous inflammation in 2003, clinical presentation and radiography findings suggested

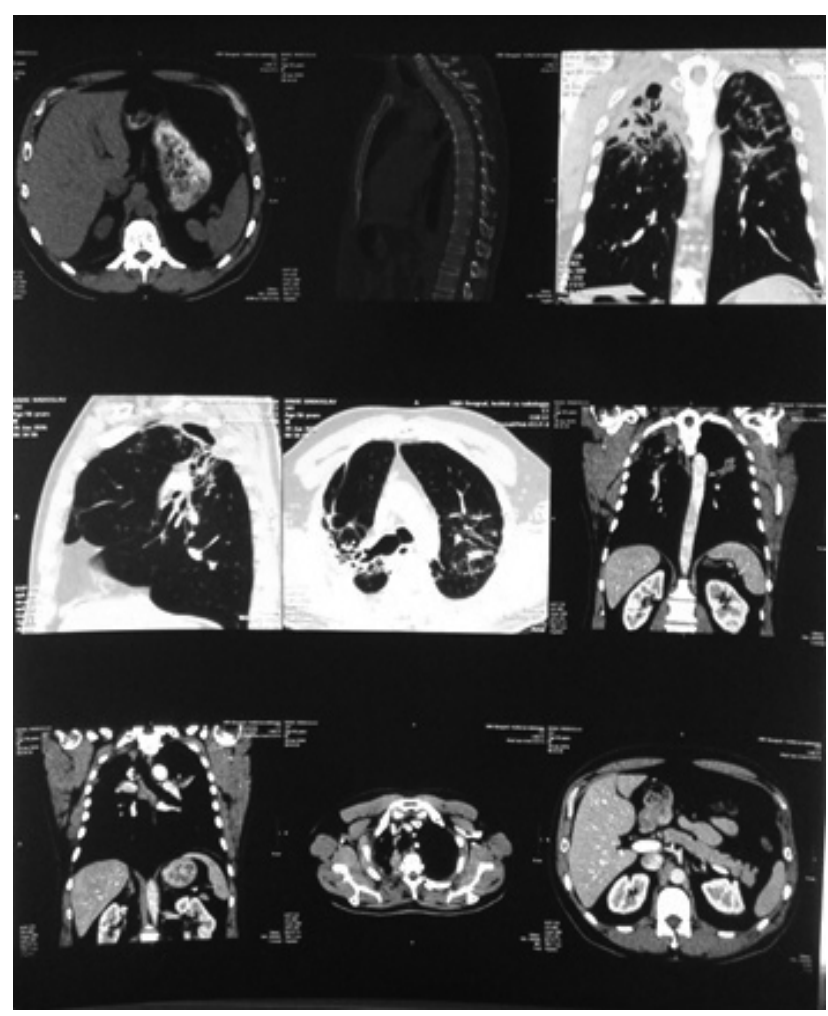

Figure 3. CT scanof thorax and abdomen from 2016. It showed cystic bronchiectasis with fibrosis in right upper lung which shifted trachea into right side. In

both lower lobes fibrous changes of lower degree were seen. Mediastinal lymph nodes wereenlarged, the biggest was right paratracheal node $(26 \mathrm{~mm})$ and infracarineal $(20 \mathrm{~mm})$. sarcoidosis with slow progression and fibrous indurative changes in upper lung lobes with the presence of lowgrade lymphocyte alveolitis.

\section{DISCUSSION}

Sarcoidosis is a condition that includes both lung findings as well as other locations. Its finding in the lungs is not specific for sarcoidosis and it is very diverse, which is why it can resemble a great number of pulmonary diseases. Because of that, diagnosing sarcoidosis in patients with only pulmonary findings can be very challenging. Imaging has an important role in the diagnosing process, even though sarcoidosis has variable appearance (7-9).

Our patient was presented only with pulmonary findings which were the only imaging finding for almost 16 years of the treatment period. After that, degenerative changes were seen in feet and hands. This was not the specific finding due to the patient's age at that time. But it should be also noted that arthritis is seen in $18 \%$ of patients as an extra-pulmonary finding, which is why doctors should pay close attention to its signs and symptoms $(4,10)$. Our study showed no correlation between the incidence of extra-pulmonary findings and duration of the disease, which is also described in the literature (4). Our study also showed that the diagnosis of sarcoidosis can take time and even though laboratory results at one point suggested tuberculosis, the final diagnosis was sarcoidosis, thanks to the revision of previous samples. The revised pathohistological finding, clinical presentation and radiography supported that diagnosis.

\section{CONCLUSION}

Sarcoidosis is a disease with ambiguous presentation. Pulmonary sarcoidosis is rare and its presentation is untypical. It is important for patients and doctors to stay determined in the process of treatment due to the fact that time needed for the diagnosis of sarcoidosis can be extended and in most cases unnecessary treatment and diagnostic tests are performed.

\section{ABBREVIATIONS}

computed tomography (CT), acidoresistent bacilli (ARB), Lowenstein-Jensen (Low), pathohistological $(\mathrm{PH})$, antituberculotic (ATL), isoniazid $(\mathrm{H})$, rifampicin (R), pyrazinamide $(\mathrm{Z})$, ethambutol $(\mathrm{E})$, streptomycin $(\mathrm{S})$, bronchoalveolar lavage (BAL), transbronchial needle aspiration (TBNA), transbronchial biopsy (TBB), Carbon monoxide $(\mathrm{CO})$ 


\section{REFERENCES}

1. Nunes H, Bouvry D, Soler P, Valeyre D. Sarcoidosis. Orphanet J Rare Dis 2007; 2:46.

2. Giovinale M, Fonnesu C, Soriano A, et al. Atypical sarcoidosis: case reports and review of the literature. Eur Rev Med Pharmacol Sci 2009; 13:37-44.

3. Wu JJ, Schiff KR. Sarcoidosis. Am Fam Physician 2004; 70:312-22.

4. Tavana S, Alizadeh M, Mohajerani SA, Hashemian SM. Pulmonary and extra-pulmonary manifestations of sarcoidosis. Niger Med J 2015; 56:258-62.

5. Silva M, Nunes H, Valeyre D, Sverzellati N. Imaging of sarcoidosis. Clin Rev Allergy Immunol 2015; 49:45-53.
6. Warshauer DM, Lee JK. Imaging manifestations of abdominal sarcoidosis. AJR 2004; 182:15-28.

7. Valeyre D, Prasse A, Nunes H, Uzunhan Y, Brillet PY, Müller-Quernheim J. Sarcoidosis. Lancet 2014; 383:1155-67.

8. Criado E, Sánchez M, Ramírez J, et al. Pulmonary sarcoidosis: typical and atypical manifestations at high-resolution CT with pathologic correlation. Radiographics 2010; 30:1567-86.

9. Spagnolo P, Sverzellati N, Wells AU, Hansell DM. Imaging aspects of the diagnosis of sarcoidosis. Eur Radiol 2014; 24:807-16.

10. Disayabutr S, Pattanaprichakul P, Ruangchira-Urai R. A case series of sarcoidosis with pulmonary involvement: various clinical and radiographic manifestations. J Med Assoc Thai 2013; 96:888-97. 